\title{
Ethnic and cultural issues of Uyghurs identity in Xinjiang region ${ }^{3}$
}

\author{
Tatyana I. Ponka, Anastasia E. Shlentova, Andrey A. Ivashkevich \\ Peoples' Friendship University of Russia (RUDN University) \\ 6 Miklukho-Maklaya St., Moscow, 117198, Russia
}

The Uyghurs are a Turkic-Muslim minority in the People's Republic of China (PRC), their native language belongs to a Turkic language family and is written on the basis of Arabic graphics, and regard themselves as culturally and ethnically close to Central Asian nations. This article deals with the issue of the Uyghur identity role in the case of the Xinjiang Uygur Autonomous Region (XUAR) in China and its manifestations in relation to Chinese policy in the region. In order to study this issue the article analyzes the Uyghurs' attitude towards the Han Chinese migrants and their reaction towards Mandarin tuition as well as the salience of Islam faith as a crucial identity marker.

Keywords: Identity; China; Uyghurs; Culture; Islam; Minorities

\section{Introduction}

Human history demonstrates that cultural differences can become a ground for intensification of disputes and tensions. Some scholars state that differences in culture can lay the ground for deep psychological animosity $[1,2]$. Others pay attention to how elements of culture may hinder an effective communication, which brings about misunderstandings and acts of violence [3].

Social identity theory, described by R. Brown [4] within the frameworks of social psychology, is founded on the idea that humans, by nature, are able to distinguish between various conditious, entities and behavior. This ability represents a functional cognitive process, which is essential for basic interactions. This ability easily leads to the formation of in-groups and out-groups division of "us" and "others", which helps individuals to build mental constructs for setting, guiding and navigating behavior and social interactions. Another important point is that individuals perceive the salience of those identities depending on circumstances and setting. The most basic one among them is when representatives of one identity encounter ones of a different identity and the latter join their group. This phenomenon and its consequences have been demon-

(C) Ponka T.I., Shlentova A.E., Ivashkevich A.A, 2018 
strated in the research, conducted by Steele, Spencer, and Aronson in 2002 [5] which explains why the issue of identity is greater in majority-minority relationships. Thus, once an identity becomes a salient aspect of an issue and reinforces the idea of "us" and "others", the dispute propensity and even riots become more likely to occur.

This analysis is dedicated to examining the case of the Xinjiang Uygur Autonomous Region (XUAR) in China, where the issue of identity has become a matter of considerable significance. The relationship between the dominant and the minor identities is defined as the centre of contemporary disputes, where minor identity, involving strong connection to history, beliefs and culture lay the foundation for the polarisation between "us" and "others" [6]. This very fact marks the relevance of the research. The main question for this analysis is: What role does the Uyghur identity play in the relative region`s case?

\section{Uyghur identity review and its factor in relations with the Han}

First, it should be kept in mind that Uyghur society is characterized by a considerable salience of religious devotion and Islam as an integral part of their lifestyle and identity as well as strengthening affiliation with the global Muslin community (Ummah). However, in the contemporary XUAR there exist some types of internal religious division, namely, the contradiction between Sunni and Shia Islam, various Sufi practices or local religious traditions and reformist orthodox practices.

Secondly, it is possible to find a various intragroup divisions within the Uyghurs, which is stated by another scholar, who examines the question of Uyghur identity, J. Rudelson. His research separates Uyghurs by geographical factor - according to certain areas of residence affiliation - and by the social groups based on occupation [7: 168]. He argues that among geographically marked groups, one can observe a certain atmosphere of local competition. For example, Uyghurs usually tend to assert that their hometown is better than any others and tend to prescribe unique character`s features to citizens of different villages and towns. Considering social groups, Rudelson describes the following three categories: peasants, merchants and intellectuals. His analysis states, poor peasants tend to identify themselves with Islamic world, whereas wealthy peasants the merchants, who may travel to other regions, are more prone to see themselves as multicultural citizenship of Chinese country. The last group, intellectuals, perceive themselves as both the People's Republic of China (PRC) citizens and a part of the Turkic ethnicity.

Another boundary-marker appeared not so long ago and distinguishes Uyghurs according to the language they were educated in: the minkaohan (in Mandarin language) and the minkaomin (in Uyghur language). This division led to the intragroup polarization as "minkaomin education is not taken seriously by non-Uyghur employers. $<\ldots>$ In turn, they [minkaomin] often resent minkaohan students as opportunistic and unfaithful to their own heritage" [8].

The existence of internal identity markers shows the hybridity of Uyghur identity. However, another researcher J. Smith Finley points out its later dynamic of consolidation, which is driven by "external" factors of a new religious, cultural and socio-economic perceived threat from Han migrants [9]. In the 1950s, the Chinese 
government launched an active policy of economic development for the region, which resulted in the construction of infrastructure - schools, hospitals, modern houses, highways and railways, and included a considerable migration policy of Han Chinese with two major goals: to provide high quality personnel and ensure the better and faster assimilation of the region and its inhabitants. At that date the region's population was quite homogenous: approximately $75 \%$ Uyghurs, less than $5 \%$ Han Chinese [10: 306]. The pace of migration has been increasing over the past half century, especially with the construction of railways and highways. This process led to the fact that the number of migrants in Xinjiang gradually began to approach the number of local residents. In 2008 the demographic comprised around 46\% Uyghur and 39\% Han Chinese [11: 121].

At the very beginning of their relations Hans and Uyghurs did not face serious disagreements [12]. However, the situation started to aggravate since "The Great Leap Forward" campaign, initiated in 1958, when some Uyghur political leaders were accused of nationalism and sent to labor camps. The famine that struck the country after the "Great leap" further intensified hostility towards the Han people. Things became even worse after The Cultural Revolution, which was aimed to remove the remnants of traditional elements from Chinese society, including symbols of religious devotion: thus, the "Red Guards" destroyed Mosques and publicly burned Korans. The consequences of the Cultural Revolution had a strong negative impact on the relationship of Hans and local ethnic groups.

Besides, if initially the Han people settled in so-called "New Towns" separated from Uyghur "Old Towns", which was the reason for limiting contacts, recently, new migrants began to settle not only in cities, but also in rural areas. In addition, the Uyghurs themselves moved to areas populated by Han migrants, as this opened up new opportunities for finding well-paid jobs, new markets and the opportunity for a better education. As a result, the interaction between Hans and Uyghurs, as well as the pressure on fragile ethnic boundaries has increased, making religiocultural differences harder to manage.

In the long run, the growth of the Han population led to the fact that, while making up the majority in some urban areas of XUAR, new migrants saw no reason and did not want to adapt to the Uygur culture. Instead, they expected the Uyghurs themselves to adapt to the Han culture [12: 173]. The situation resulted in the Uyghurs accusing the Hans of great chauvinism and the process of a voluntary social segregation. According to J. Smith Finley, it serves as a means of differentiating a united ethnic identity. With the exception of business, the Uyghurs almost do not communicate with the Hans and demonstrate a public condemnation of Uyghur-Han connections, explaining it by the Uyghur Islam-rooted national customs, which are difficult for non-Muslims to understand [9].

Moreover, as the British researcher Joan N. Smith notes, from the 1990s the Uighurs started deliberately intensifying and exaggerating the cultural and religious differences between themselves and the Han as a means of protecting their ethnicity from disappearance among Chinese migrants and differentiating a united ethnic identity in reaction to perceived competition from Han immigrants in various social 
spheres. This tendency of intentional and voluntary segregation is described by a public disapproval of Uyghur-Han intermarriages and broad unwillingness to communicate with the Hans in various social situations that is explained by the Uyghur Islamrooted national customs, which are difficult for non-Muslims to understand [12].

It should be noted, that neither side wants to compromise the situation and strictly adheres to its stereotype of behavior. The outcome of this was the deliberate confrontation of the two completely different types of life patterns, and Uyghurs` current attitude towards the Han is characterized by bitterness and a sense of injustice.

\section{Attitude towards the institutionalization of Chinese language}

Another factor contributing to the consolidation of Uyghurs in opposing their ethnicity to the Han people was the issue of language. During the second half of the 20th century Mandarin became an official language in public and educational institutions. As a result, urban Uyghurs living in cities were caught in a network of socio-economic disadvantages. In order to have a chance for a good job, the Uyghurs have to have the same level of education as the Han migrants, which is impossible without studying at school where teaching is conducted in Chinese (a Han Chinese school). All this led to a large level of unemployment among the Uyghur population, and increasingly the Uyghurs' bitterness against the Han occupying the "white-collar posts" [9: 51-53]. So, the overwhelming majority of Uyghurs feel that in order to succed on the job market they have to master Mandarin.

Since the mid-1980s the PRC government has taken the course for gradual institution of compulsory Chinese education to achieve successful minority's inclusion and full minority-Han communicability. To support this goal, Uyghur language schools began to teach Chinese in the third grade instead of the first year of middle school. In addition, intensive teacher training was implemented. By the beginning of 2015, more than 2 million ethnic minority students (which accounts for $75 \%$ of all kindergarten, primary and middle students) have been studying under bilingual program; most of them are from cities and only a small amount - from southern rural areas [13]. The Communist Party of China (CPC) has repeatedly outlined the salience of bilingual education for minority children and regional development [13, 14]. However, a number of Uyghurs complain about such policy, because they perceive it to be an assault on their culture. The Uyghur Human Rights Project (UHRP) voices concern that there are not many Uyghur schools compared to the Chinese ones and they receive less amount of public financing; the majority of school textbooks are only written in Mandarin languahe; with the exception of minority languages and literature, courses at Xinjiang University are taught solely in Chinese [15]. In addition, there appeared common negative effects of the increased mandarinfocused bilingual education in Xinjiang, which always followed the situations when minority-children have to study in a foreign language [15]. The UHRP insists that the method of language immersion as currently practiced in XUAR results in a poor education for minority students, as, firstly, the added pressure of learning in a second language has repeatedly proved to have negative effect on a child's development and 
motivation, which in turn leads to frustration and higher dropout rates, and, secondly, vast majority of Han Chinese teachers are not bilingual and can only speak Mandarin $[15,16]$.

Besides, the situation is even more complicated by the fact that many Uyghur parents do not want to send their children to the Han schools because, on the one hand, they fear ethnic discrimination of their children by Han Chinese classmates, and on the other - wish to preserve the national Uygur culture through Uyghur education [17: 24].

Thus, Uyghurs appear to be caught in the network of collisions. On the one hand, being a part of a multinational country implies that they should objectively master the national common language to succeed. On the other hand, the fact, underlined by some scholars and the UHRP that Uyghurs see their language as a crucial identity marker, causes the opposition towards the Mandarin tuition. The conditions for children`s ability to successfully master Chinese is complicated by the deep-rooted tradition in Uyghur society to only speak in native language among themselves. As a result, students speak and write in Chinese at school (and sometimes Uyghur teachers are not fluent enough in Chinese), and then go home where all conversations are done in Uyghur language. What is more, as it was mentioned above, Hans themselves are reluctant to adapt to Uyghurs' traditions and use their language, even those occupying official positions [18, 9: 169].

\section{Culture and religion}

The CPC expresses strong disagreement with accusations of oppression of the minorities`right to freedom of religion. However, a strict government policy aimed at religion's control does take place. As Xi Jinping pointed out at the Central Religious Work Conference in 2016, religious groups should "merge [their] doctrines with Chinese culture" while keeping religion out of politics, government affairs, and education [19]. Some measures clearly represent the intentions to interfere in and regulate the most personal aspects of Muslims` lives. So, it is officially forbidden to attend the mosque before age 18. Another example is an announcement made by the Shayar County government that called for the citizens to inform the authorities of "suspicious conduct of 18 different religious activities"[20] for the reward. Some measures clearly represent the intentions to interfere in and regulate the most personal aspects of Uyghurs' lives. From time to time, there appears information considering the ban on fasting during Ramadan, which manifested in a way when Uyghurs were obliged to eat at work or at school. One of the Uyghur Human Rights Project reports expresses concern about recent measures preventing Uyghurs from choosing state restricted names for their newborn children, as they are determined to be an expression of extremist Islam or "splittism" [21].

All these cases embody a common attitude towards Islam, which reigns in the CPC. However, Islam and its rituals play a central role in Uyghur identity, and a significant number of Uyghurs express discontent with government's supervision over their religious practicies and perceive Islam as "the sole remaining certainty in a society which allows us [Uyghurs] no space" [9: 281]. Some government initiatives may be perceived painfully if they somehow contradict to Islam tradi- 
tions. For example, the family planning policy (despite being even more flexible than the same policy towards the Han - rural Uygurs in Xinjiang have been allowed to have maximum of three children and urban population - of two) met a high complaint among Uyghurs as they saw children as "Allah's blessing".

During her research, J. Smith Finley states that one can observe a revival of Islam within the Uyghur community, which portrays both a search for religious purity and a way to express and demonstrate its Identity and protect it from disappearance. The other reason is a consequential defensive reaction against official attitude, which tends to equate Islam and terrorism or extremism as well as portray Uyghurs as susceptible to the "Three Evil Forces" of separatism, terrorism, and extremism [22]. According to one of J. Smith Finley's respondents, "I suppose Islam is stronger now because the government is trying to block religious activities. If the government tries to block or limit Islam, then people's faith only becomes stronger" [9: 165].

Another salient identity maker is clothing and appearance, especially in Islam tradition. However, as it was aforementioned, the Uyghurs face some government initiative to constrain Muslims in this sphere as well by placing restrictions on the practice of Islam traditions. So, in 2014 the authorities of Qaramay and Ghulja issued the temporary ban on using the public transport for so-called "Five People", which implied men with long beards, women wearing hijab, jilbab or veils, and individuals wearing clothes with the logo of a crescent moon and stars, which are attributes of the East Turkestan flag. [23]. The prohibition was explained by the need to strengthen public transport safety and combat manifestations of religious extremism. This policy was followed by the permanent banning regulation which was passed at the $21 \mathrm{st}$ Meeting of the 15th Standing Committee of the Urumqi People's Congress in December of the same year and came into power on February 1, 2015 [24]. This regulation implied a total ban on attending public spaces in the XUAR capital, Urumqi, for individuals wearing full-faced Islamic veil and full-body covering. The implemented ban was again tied to security reasons: in order not to impede police personnel to identify individuals, as well as to the fact that those types of clothing were associated with religious extremism and that Islamic clothing is "abnormal" attire [25]. In this way, the new policy happens to be imprudent and fails to accept the nuanced identity symbols for Muslin communities, by belittling their significance to a simple clothing choice.

Nevertheless, some scholars [9, 25-26] argue a growth of Uyghurs wearing veils and long beards following the ethnic clashes in 1990-s and 2009, which can be considered as an example of how representation of identity might change as a reaction to outside pressure as a defense of one's identity.

In 2003 the state's Information Office published a "White paper", which stated that religious extremists had "politicized the unstandardized geographical term 'East Turkistan', and fabricated an 'ideological and theoretical system' on the socalled 'independence of East Turkistan' on the basis of the allegation cooked up by the old colonialists" [27]. This rhetoric has changed over time, it is emphasized that "religious extremism betrays and distorts religious doctrines, deludes and deceives the public, particularly young people, with their fallacies, and changes some people into extremists and terrorists completely under its control" [28]. However, the main 
idea, that the government will continue taking "active measures to make religions to adapt to socialist society, and prevents the use of religion in interfering in the administrative, judicial, educational and other social affairs" [28]. Such stance objectively causes grievance in Muslim community, as markers of Islam faith and culture traditionally manifest in all their life spheres. Moreover, this process of labeling cultural and religious practices as abnormal, and linking them to violent extremism creates an association of the Uyghur identity with terrorism. So, the CPC by associating Uyghurs with terrorism - even if indirectly - represents them as a "foe" and establishes the foundation which strengthens the boundary definition of Uyghurs ' "self" contrast to Hans ' "other". Moreover, taking into account identities are flexible, the Chinese government by treating Uyghurs as an "enemy" may itself create a self-fulfilling prophecy, potentially resulting in them behaving as such.

\section{Conclusion}

In response to the main research question "What role does the Uyghur identity play in the relative region's case?" it can be stated that the idea of "Us against Them" and salience of identity is clearly visible, and the analysis supports the idea that the issue of identity serves as a battleground in Xinjiang region. However, the increasing manifestation of Uyghurs identity can be considered to be more of the effect rather than the reason of the tensions, as it initially did not provoke any problems with the government. Yet the latest tendencies demonstrate a significant growth of identity's issue for Uyghurs, which fuels the disagreements, and may prolong them to a point of intractability.

The research concludes that the Uyghurs close in upon themselves and begin to react painfully to everything new that is connected with Chinese culture and lifestyle, which may also be caused by two facts. Firstly, identity boundary symbols have become a way of an indirect resistance to the perceived threat of the PRC policy. Secondly, as Islam is a cornerstone of Uyghurs ' culture, the policy of treating it as a violent force related to terrorism and extremism leads to the animosity and adds more disputes. In addition, there is some visible hostility towards Han migrants, as Uyghurs try to emphasize their differences with Chinese and strengthen the boundaries between the two identities. Such pattern, which sharply distinguishes different types of cultures, inevitably leads to tensions.

Nevertheless, it would be improper to label this case as an "ethnic conflict". Instead, the issues of Xinjiang would be more correctly to describe as partly a failure of China to successfully adress minority`s wishes and effectively integrate them.

\section{REFERENCES}

[1] Connor W. Ethnonationalism: The Quest for Understanding. Princeton, New York: Princeton University Press; 1994.

[2] Huntington SP. The Clash of Civilizations and the Remaking of World Order. New York: Simon and Schuster; 1996. 
[3] Comor E. The Role of Communication in Global Civil Society. International Studies Quarterly. 2001 Sept;45(3):389-408. doi: 10.1111/0020-8833.00206.

[4] Brown R. Social Identity Theory: Past Achievements, Current Problems and Future Challenges. European Journal of Social Psychology. 2000; 30(6):745-778. doi: 10.1002/ 1099-0992(200011/12)30:6<745::AID-EJSP24>3.0.CO;2-O.

[5] Steele CM, Spencer S, Aronson J. Contending with Group Image: The Psychology of Stereotype and Social Identity Threat. Advances in Experimental Social Psychology. 2002.(34): 379-440. doi: 10.1016/S0065-2601(02)80009-0.

[6] Kaldor M. Identity and War. Global Policy. 2013 Nov;4(4):336-346. doi: 10.1111/17585899.12084.

[7] Rudelson JJ. Oasis Identities, Uyghur Nationalism Along China's Silk Road. New York: Columbia University Press; 1997.

[8] Palmer J. Blood and Fear in Xinjiang. Foreign Policy. 2014 March 2. Available at: https:// foreignpolicy.com/2014/03/02/blood-and-fear-in-xinjiang/. Accessed: Nov 4, 2018.

[9] Smith Finley J. The Art of Symbolic Resistance: Uyghur Identities and Uyghur-Han relations in Contemporary Xinjiang. Leiden and Boston: Brill, 2013.

[10] Millward JA. Euroasian Crossroads: A History of Xinjiang. London: Hurst \& Co; 2007.

[11] Howell A, Cindy Fan C. Migration and Inequality in Xinjiang: A Survey of Han and Uyghur Migrants in Urumqi. Eurasian Geography and Economics. 2011;52(1):119-139. doi: 10.2747/1539-7216.52.1.119.

[12] Smith JN. Making Culture Matter: Symbolic, Spatial and Social Boundaries between Uyghurs and Han Chinese. Asian Ethnicity. 2002;3(2):153-174. doi: 10.1080/ 14631360220132718.

[13] More students in Xinjiang receive bilingual education. Xinhua. 2015 Oct 7. Available at: http://www.xinhuanet.com/english/2015-10/07/c_134689471.htm; Accessed: Oct 30, 2018.

[14] Bilingual education boosts development in Xinjiang. China News Service Website. 2015 Sept 10. Available at: http://www.ecns.cn/2015/09-10/180690.shtml. Accessed: Oct 30, 2018.

[15] Uyghur Human Rights Project. Uyghur Language Under Attack: The Myth of "Bilingual" Education in the People's Republic of China. 2007 July 24. Available at: https:// uhrp.org/uaa-and-uhrp-reports/uyghur-language-under-attack-myth-“bilingual"-education-peoples. Accessed: Oct 20, 2018.

[16] Uyghur Human Rights Project. Voices on Education: China's Assimilative "Bilingual Education" Policy in East Turkestan. 2015 May 20. Available at: https://uhrp.org/pressrelease/uhrp-releases-report-bilingual-education-east-turkestan - uyghur-voices-education.html. Accessed: Oct 27, 2018.

[17] Pshencoff PS. The problem of ethnic isolation in the formation of the national identity of the indigenous population on the example of the Xinjiang Uygur Autonomous Region of the People's Republic of China. Vestnik Chuvashskogo Universiteta. 2007;4:21-26. (in Rus).

[18] Mackerras C. Some Issues of Ethnic and Religious Identity among China's Islamic Peoples. Asian Ethnicity. 2005;6(1):3-18. doi: 10.1080/1463136042000309017.

[19] China Focus: Xi calls for improved religious work. Xinhua. 2016 Apr 23. Available at: http://www.xinhuanet.com//english/2016-04/23/c_135306131.htm. Accessed: Nov 7, 2018.

[20] World Uyghur Congress. Attempt to standardise Uyghur traditional clothing latest excessive intrusion into personal religious lives of Uyghurs. 2014 May 15. Available at: http://www.uyghurcongress.org/en/?p=22512\%20Attempt $\% 20$ to $\% 20$ standardize $\% 20$ 
Uyghur $\% 20$ traditional $\% 20$ clothing $\% 20$ latest $\% 20$ excessive $\% 20$ intrusion $\% 20$ into $\% 20$ personal\%20religious\%20lives\%20of\%20Uyghurs. Accessed: Oct 16, 2018.

[21] Uyghur Human Rights Project. BRIEFING: Ban on "Islamic" names an absurd intrusion into Uyghurs' private lives. 2017 May 4. Available at: https://uhrp.org/uaa-and-uhrpreports-and-briefings-press-releases/briefing-ban-"islamic"-names-absurd-intrusion. Accessed: Oct 16, 2018.

[22] Leibold J. Creeping Islamophobia: China's Hui Muslims in the Firing Line. China Brief. 2016 June 10;16(10):1-19.

[23] Minitrue: No Beards on Xinjiang Buses. China Digital Times. 2014 Aug 5. Available at: https://chinadigitaltimes.net/2014/08/minitrue-beards-xinjiang-busses/. Accessed: Nov 10, 2018.

[24] The City of Urumqi Prohibition on Wearing Items That Mask the Face or Robe the Body. ChinaFile. 2015 Feb 4. Available at: http://www.chinafile.com/reporting-opinion/ features/city-urumqi-prohibition-wearing-items-mask-face-or-robe-body. Accessed: Nov 10, 2018.

[25] Leibold J, Grose T. Why China is banning Islamic veils. La Trobe. 2015 June 2. Available at: https://www.latrobe.edu.au/news/articles/2015/opinion/why-china-is-banningislamic-veils. Accessed: Nov 10, 2018.

[26] Page J. In Xinjiang, Veils Signal Conservative Shift Among Uighurs. The Wall Street Jornal. 2014 July 31. Available at: https://www.wsj.com/articles/in-xinjiang-veils-signal-conservative-shift-among-uighurs-1406830554. Accessed: Oct 12, 2018.

[27] History and Development of Xinjiang. White Paper. The State Council Information Office of the People's Republic of China. 2003 May. Available at: http://www.gov.cn/english/official/2005-07/28/content_17948.htm. Accessed: Nov 8, 2018.

[28] Freedom of Religious Belief in Xinjiang. White Paper. The State Council Information Office of the People's Republic of China. 2016 June 2. Available at: http://english.gov. cn/archive/white_paper/2016/06/02/content_281475363031504.htm. Accessed: Nov 12, 2018 .

\title{
Этнические и культурные аспекты уйгурской идентичности в регионе Синьцзянь
}

\author{
Т.И. Понька, А.Е. Шлентова, А.А. Ивашкевич \\ Российский университет дружбы народов \\ ул. Миклухо-Маклая, 6, Москва, Россия, 117198
}

Уйгуры являются тюркским меньшинством, исповедующим ислам, в составе Китайской Народной Республики (КНР). Уйгурской язык относится к тюркской языковой группе и близок к узбекскому, в письменности которого используется арабская графическая основа. Культурно и этнически данный этнос относит себя к Центрально-азиатским нациям. Данная статья рассматривает вопрос уйгурской идентичности в Синьцзян-Уйгурском автономном районе (СУАР) и ее проявления по отношению к политике Китая в 
регионе. С целью исследования данного вопроса в статье представлены и осмысленны темы отношения уйгуров к ханьским мигрантам и их реакции на обучение на китайском языке, а также значение Ислама в качестве основополагающего маркера идентичности.

Ключевые слова: идентичность, Китай, Уйгуры, Ислам, культура, меньшинства

\section{Информация об авторах / Information about the authors}

Понька Татьяна Ивановна, кандидат исторических наук, доцент кафедры теории и истории международных отношений факультета гуманитарных и социальных наук Российского университета дружбы народов. E-mail: ponka-rudn@mail.ru.

Шлентова Анастасия Евгеньевна, соискатель степени магистра кафедры теории и истории международных отношений факультета гуманитарных и социальных наук Российского университета дружбы народов. E-mail: bobcat24@rambler.ru.

Ивашкевич Андрей Андреевич, соискатель степени магистра кафедры теории и истории международных отношений факультета гуманитарных и социальных наук Российского университета дружбы народов. E-mail: anjay3960@gmail.com.

Tatyana I. Ponka, PhD in History, Associate Professor of the Department of Theory and History of International Relations, Faculty of Humanities and Social Sciences at RUDN University. E-mail: ponka-rudn@mail.ru.

Anastasia E. Shlentova, master's degree candidate of the Department of Theory and History of International Relations, Faculty of Humanities and Social Sciences at RUDN University. E-mail: bobcat24@rambler.ru.

Andrey A. Ivashkevich, master's degree candidate of the Department of Theory and History of International Relations, Faculty of Humanities and Social Sciences at RUDN University. E-mail: anjay3960@gmail.com.

\section{Для цитирования / For citation}

Понька Т.И., Шлентова А.Е., Ивашкевич А.А. Этнические и культурные аспекты уйгурской идентичности в регионе Синьцзянь // Вестник Российского университета дружбы народов. Серия: Всеобщая история. 2019. Т. 11. № 1. С. 34-43. http://dx.doi. org/10.22363/2312-8127-2019-11-1-34-43

Ponka T.I., Shlentova A.E., Ivashkevich A.A. Ethnic and cultural issues of Uyghurs identity in Xinjiang region // RUDN Journal of World History. 2019. Vol. 11. No. 1. Pp. 34-43. http://dx.doi.org/10.22363/2312-8127-2019-11-1-34-43

Рукопись поступила в редакцию / Article received: 17.10 .2018 